UDC 618.14-002-036.12-07

DOI: $10.21668 /$ health.risk/2017.4.06.eng

\title{
HIGH RISKS OF SOMATIC PATHOLOGY IN WOMEN WITH CHRONIC ENDOMETRITIS
}

\section{E.G. Kobaidze, M.M. Padrul}

Perm State Medical University named after Academician E. A. Wagner, 26 Petropavlovskaya Str., Perm, 614000, Russian Federation

As women fertility is obviously decreasing at present, a number of people who, being at the reproductive age, suffer from various diseases is only growing and it is truly a vital issue. Chronic endometritis which is a problem in contemporary gynecology and reproductive performance studies may cause menstrual function disorders, anemia, and chronic pelvis pains syndrome. Our research goal was to assess risks of somatic pathology evolvement and life quality of women suffering from chronic endometritis. The focus group was made up of 42 patients at their fertile age who suffered from chronic endometritis $(n=42) ;$ the reference group consisted of practically healthy females at the same age $(n=33)$ who applied to a gynecologist in order to make a choice on a contraceptive.

We detected that women with chronic endometritis had somatic pathologies much more frequently that women from the reference group; such pathologies included chronic gastritis, functional disorders in the bowels, gall-bladder diseases, urinary system diseases, and chronic rhinopharyngitis (relative risks varied from 1.25 to 4.62; $p<0.05)$. High somatic pathology parameters indicate there is a decrease in immunologic protection and non-specific reactivity to pathologic changes in molecular mechanisms involving tissue and cellular homeostasis disorders. Patients form the focus group had lower life quality, weaker endurance and greater fatigue, lower emotional and social activity.

When doctors of all specialities treat patients with chronic endometritis they are advised to apply healthrestoring treatment at any stage when a patient applies for medical assistance (and not only when she is getting ready for a pregnancy). We highlight the necessity to create individual sets of pharmaceuticals, physiotherapy and balneal techniques, and diet therapy for basic metabolic processes recovery, antioxidant processes recovery, immunologic protection and non-specific reactivity improvement. It is also necessary to treat not only gynecological pathology, but also a concomitant somatic one.

Key words: reproductive age, chronic inflammatory pathology, somatic diseases, life quality, chronic endometritis, reproductive health.

The World Health Organization sticks to the following reproductive health definition: "Reproductive health is a state of complete physical, mental, and social wellbeing; it does not mean simple absence of any diseases related to the reproductive system, its functions, and processes". As female fertility is going down nowadays, more and more people of reproductive age turn out to have various diseases, both of somatic and gynecological genesis, which can cause infertility, and it remains a very serious issue. A number of auxiliary reproductive technologies aimed at treating infertility has grown over the last years. However, there are certain pathologies which are too difficult to treat and which cause unsuccessful embeddings in case when auxiliary reproductive technologies are applied. Particularly, nowadays the

(C) Kobaidze E.G., Padrul M.M., 2017

Ekaterina G. Kobaidze - Candidate of Medical Science, Associate Professor of the Department of Obstetrics and Gynecology (e-mail: eka7i@yahoo.com; tel.: +7 (342) 236-39-30).

Mikhayl M. Padrul - Doctor of Medical Science, Professor, Head of the Department of Obstetrics and Gynecology (e-mail: m-padrul@mail.ru; tel.: +7 (342) 236-39-30). 
uterine factor is becoming a complicated and poorly treatable infertility issue all over the world. Epidemiological parameters of chronic endometritis in women of fertile age are quite different, from $1 \%$ to $70 \%$; but its contribution into reproduction disorders is not under any discussion $[9,12]$. This pathology outcomes are individual in each case, as it is hardly possible to predict endometrial functional state in these patients in spite of great number of contemporary laboratory-diagnostic techniques for examining uterus mucous tunic state. Chronic endometritis can become a serious problem for a patient: it causes menstrual disorders in women, anemia, chronic pelvis pain syndrome, chronic fatigue, infertility, and it lowers overall life quality. We should also note that oncologic gynecological pathologies increase in patients with chronic diseases in their case history and it accordingly proves it is necessary to get better insights into the issue $[10,14]$. Inflammation process under chronic endometritis progresses wavelike, specific clinic symptoms are absent, etiological agents in endometrium are hard to identify, physiological factors of protection from damage fail, disorders in endometrium receptivity evolve, a doctor and a patient tend to underestimate clinical signs, the disease can possibly have autoimmune character, and so, etiotoropic therapy issue arises; all the above-said characterizes chronic endometritis nowadays.

When endometritis occurs, acute or chronic inflammation evolves and a whole body is involved in it to a certain extent. Endogenous protection systems and search for universal regulators of physiological body functions attract doctors' closest attention when it comes to complications prevention and rehabilitation. When pathogenic factors exert their impacts on a body, basic inflammatory and immune response schemes start to work: inflammation occurs, antigen-representing cells start to function, an adaptive immune response evolves, immune lymphocytes-effectors migrate, antibodies concentrations in inflammation focus grow, antigens and tissues damaged by pathogens are destroyed, and decay products are discharged from a body by its excretory systems, namely the liver, kidneys, bowels, etc. [2, 7, 15]. Chronic inflammation pathologies occurrence in the gastrointestinal tract or urinary tracts are now considered by practicing gynecologists as related to chronic endometritis. Extragenital chronic inflammation focuses can contribute into a decrease in a body adaptive abilities and make for chronic inflammation pathologies in the uterus. There are opinions that any chronic infection focus in a body, including chronic adnexitis, can be a source of infection which penetrates the gall bladder [3], thus causing chronic non-calculous cholecystitis. We should note that possible reserve impacts exerted by inflammations in the gall bladder on endometrium state are not studied enough. There are some data in literature on pathologic impacts exerted by chronic tonsillitis on menstrual function development in girls and on pregnancy complications [6]. There are also some data on microflora persisting in endometrium of patients suffering from chronic endometritis being similar to that occurring in the palatine tonsils [11]. Negative influence which chronic pyelonephritis has on pregnancy course is beyond any questions now $[4,5$, 13]. But its occurrence in gynecological patients is not well examined. And as a number of healthy women is decreasing now, it is undoubtedly vital to assess their life quality. Therapeutic approach improvement is not possible without imple- 
mentation of recommendations obtained on the basis of such research.

Our research goal was to assess life quality and risks for somatic pathology occurrence in women suffering from chronic endometritis.

Data and methods. We performed our research in a form of clinical analytical prospective analysis. We examined 75 women of reproductive age permanently living in Perm (in 2015 and 2017). The examined women were divided into 2 groups: the first one was made of practically healthy women $(n=33)$, who applied to a doctor in order to make a choice on a contraceptive; the second groups was made of patients $(n=42)$ suffering from chronic endometritis. We used the following criteria to select and include women into our sampling:

- chronic endometritis was diagnosed and the diagnosis was verified by morphologic examinations;

- the disease was diagnosed more than 1 year ago;

- there was no acute somatic pathology or an exacerbation of the chronic one;

- absence of any signs proving there was exacerbation of chronic inflammatory pathology in small pelvis organs (chronic salpiginitis, oophoritis, endometritis, cervicitis, vaginitis).

Complex examinations performed on patients included passport data analysis, case history analysis, menstrual and reproductive functions assessment, general clinical and gynecological research, somatic pathologies detection, general clinical laboratory tests, life quality assessment via SF-36, and statistical analysis techniques.

SF-36 questionnaire is a non-specific one aimed at life quality (LQ) assessment. It is widely used in conducting research on life quality of healthy population and groups of patients with various chronic dis- eases. Life quality was analyzed as per several scales $[1,8,16,17]$ :

1. Physical Functioning or PF. This scale shows to what extent physical state limits physical loads; low scoring means a respondent's physical activity is significantly limited by his or her health.

2. Role-Physical Functioning or RP. This scale determines how physical state of a person influences his or her everyday life; low scoring means that a person faces certain limitations in his or her everyday life caused by his or her health state.

3. Bodily pain or BP. This scale allows to find out how intense a pain syndrome is and how it influences an examined person's ability to pursue his or her everyday activities; low scoring also means that everyday activities are seriously limited because of pain.

4. General Health or GH. This scale shows how a woman assesses her health and her resistance to diseases; low scoring proves there is health deterioration.

5. Vitality or VT. The scale is based on subjective feelings of a respondent and allows to assess whether he or she suffers from excessive fatigue or on the contrary is full of energy; low scoring means fatigue is excessive.

6. Social Functioning or SF. This scale allows to assess satisfaction with social activity level; accordingly, low scoring proves social activities are also low.

7. Role-Emotional or RE. The scale shows how emotional state influences a patient's everyday activities; low scoring means that working capacity is reduced due to poorer emotional state.

8. Mental Health or MH. The scale allows to assess patients' moods; low scoring proves a patient has increased anxiety.

Parameters on each scale vary from 0 to 100 scores, where 100 means absolute health. The higher scoring is, the higher 
life quality is and the better health is; the results are given in scores as per 8 scales made up in such a way that a higher scoring means a better life quality $[16,17]$. Parameters as per 2 groups were assessed and represented by the median (Me) and a percentile interval 25-75. We applied distribution-free techniques (Mann-Whitney test for comparing two independent samplings) to compare both groups and examine possible correlations. To analyze dependences between a frequency of a parameter occurrence (somatic and gynecologic pathology) in a group, we applied chi-square criterion $(\chi 2)$. We analyzed discrepancies between groups as per parameters occurrence frequencies also with $\chi 2$ criterion. We calculated odds relation (OR) with 95\%confidence interval and applied relative risk with $95 \%$-confidence interval as a way to assess risk factors and possibility of health disorders in female patients.

Results and discussion. Women from the first group were from 19 to 44 (average age was $30.90 \pm 7.09$ ); from the second, from 21 to 44 (average age was $34.11 \pm 4.79)$. Reproductive case history analysis in the first group revealed the following peculiarities: 11 women had childbirth in their case history $(33.33 \pm 16.72 \%)$; 5 miscarriages which happened during first 5 gestation weeks were detected in $15.15 \pm 12.71 \%$ women, $\chi^{2}=3.46 ; p=0.06$; we didn't detect any frozen pregnancies in this group; medical abortions were made in $24.24 \pm 15.2 \%$ (8) cases, $\chi^{2}=6.97 ; p=0.008$, that is, frequency of this parameter occurrence in this group was statistically significant; $96.97 \pm 6.08 \%$ women practiced birth control and used condoms to protect themselves from unwanted pregnancies, and it proved that frequency of this parameter occurrence was statistically significant for this category of the examined women $\left(\chi^{2}=58.30 ; \mathrm{p}<0.001\right)$.
Our analysis of gynecological case history which patients from the 1 st group had revealed that $6.06 \pm 8.46 \%$ women suffered from such proliferative uterus diseases as leiomyoma, and we didn't detect adenomyosis in this group. We analyzed frequency of chronic reproductive system inflammations occurrence and revealed that women didn't have chronic salpiginitis, adnexitis, or cervicitis; chronic cervicitis led to surgery on the uterine neck in 2 patients $\left(6.06 \pm 8.46 \%, \chi^{2}=0.52 ; p=0.473\right)$. Menstrual cycle characteristics revealed that menarche occurred timely in $87.88 \pm 11.57 \%$ (29) women and we didn't detect any other menstrual disorders in this group.

Reproductive case history analysis performed on women suffering from chronic endometritis revealed the following: $57.14 \pm 15.42 \%$ (24) patients had primary and secondary infertility, $\chi^{2}=30.86$; $\mathrm{p}<0.001 ; 14$ patients $(33.33 \pm 14.69 \%)$ had childbirth, $54.76 \pm 15.51 \%$ women had medical abortions $(p<0.001)$, and it indicated that frequency of this parameter occurrence in this patients' group was statistically significant. Pregnancy had an unfavorable outcome, namely miscarriage or frozen pregnancy, in $26.19 \pm 13.7 \%$ $\left(\chi^{2}=10.46 ; p<0.001\right)$ cases and it indicated that frequency of this parameter occurrence among these patients was also statistically significant. $14.29 \pm 10.9 \%$ (6) women suffered from proliferative uterus diseases (leiomyoma) and frequency of this parameters occurrence was also statistically significant, $\chi^{2}=4.49 ; \mathrm{p}=0.034$. Adenomyosis was detected in $9.52 \pm 9.15 \% \quad(4), \quad \chi^{2}=2.36$; $\mathrm{p}=0.124$, that is, the parameter was not statistically significant in this group. Our analysis of chronic reproductive system inflammations revealed that $40.48 \pm 15.3 \%$, $\left(\chi^{2}=18.88 ; \mathrm{p}<0.001\right)$ suffered from chronic salpiginitis and adnexitis; 47.62 $\pm 15.56 \%$ $(\mathrm{p}<0.001)$, from chronic cervicitis; 
$52.38 \pm 15.56 \%(\mathrm{p}<0.001)$ patients had surgery on the uterine neck in their case history. Women suffering from chronic endometritis had various menstrual function disorders in $\quad 69.05 \pm 14.41 \%$ cases $\left(\chi^{2}=10.46 ; \quad \mathrm{p}<0.001\right), \quad$ algomenorrhea
$(28.57 \pm 14.08 \% ; \quad p<0.001)$ and profuse menses $(19.05 \pm 12.24 \%$ patients; $p<0.001)$ were statistically significant. Comparative characteristics of all the above mentioned parameters is given in Table 1 .

Table 1

Comparative characteristics of the obstetric-gynecological case history between two groups

\begin{tabular}{|l|c|c|c|c|c|c|}
\hline \multicolumn{1}{|c|}{ Signs } & $\begin{array}{c}\text { Groups } \\
(\mathrm{n}=33) \%\end{array}$ & $\begin{array}{c}\text { Groups 2 } \\
(\mathrm{n}=42) \%\end{array}$ & $\mathrm{Chi}^{2}$ & $\mathrm{R}$ & OR & CI 95\% \\
\hline Child birth & $33,33 \pm 16,0$ & $33,33 \pm 14,6$ & 0,061 & 0,805 & 1,000 & 0,$38 ; 2,63$ \\
\hline Infertility & 0 & $57,14 \pm 15,4$ & 15,584 & $0,001^{*}$ & 416,00 & $25 ; 4195,12$ \\
\hline Medical abortion & $24,24 \pm 15,0$ & $54,76 \pm 15,5$ & 5,896 & $0,015^{*}$ & 3,783 & 1,$39 ; 10$ \\
\hline Miscarriage & $15,15 \pm 12,0$ & $26,19 \pm 13,7$ & 0,765 & 0,382 & 1,987 & 0,$61 ; 6,43$ \\
\hline Frozen pregnancy & 0 & $26,19 \pm 13,7$ & 4,252 & $0,039^{*}$ & - & - \\
\hline Menstrual dysfunctions & 0 & $69,05 \pm 14,4$ & 22,517 & $0,001^{*}$ & - & - \\
\hline Leiomyoma & $6,06 \pm 8,4$ & $14,29 \pm 10,9$ & 0,591 & 0,442 & - & - \\
\hline Adenomyosis & 0 & $9,52 \pm 9,2$ & 0,799 & 0,371 & - & - \\
\hline Chronic salpiginitis & 0 & $40,48 \pm 15,3$ & 8,527 & $0,003^{*}$ & - & - \\
\hline Chronic adnexitis & 0 & $40,48 \pm 15,3$ & 8,527 & $0,003^{*}$ & - & - \\
\hline Chronic cervicitis & 0 & $47,62 \pm 15,5$ & 11,234 & $0,001^{*}$ & - & - \\
\hline Surgery on the uterine neck & $6,06 \pm 8,4$ & $52,38 \pm 15,5$ & 16,155 & $0,001^{*}$ & 17,050 & 3,$61 ; 80,56$ \\
\hline Contraception & $96,97 \pm 6,08$ & $61,9 \pm 15,1$ & 7,716 & $0,005^{*}$ & 0,000 & - \\
\hline
\end{tabular}

Note:* - means that statistically significant discrepancies in a parameter occurrence frequency were detected between healthy women and those suffering from chronic endometritis

When we compared analyzed parameters in healthy women and in female patients with chronic endometritis we revealed that there were statistically significant discrepancies in occurrence frequency of medical abortion (made to get rid of $\chi$ unwanted pregnancy, the parameter was higher in patients with chronic endometritis), chronic adnexitis and salpiginitis, chronic cervicitis, frozen pregnancy, and infertility.

As per body mass index, healthy women from group I were divided into the following sub-groups: $23(69.7 \pm 16.3 \%)$ out of 33 women had normal parameters (18.50-24.99); 10 (30.3 $\pm 16.3 \%)$ women had excessive body weight and 1st degree obesity $\left(\chi^{2}=9.55 ; p=0.002\right)$. A share of women with normal body mass in group 2 amounted to $69.05 \pm 14.41 \%$

(29);
$30.95 \pm 14.41 \%$ (13) had lipid metabolism disorders; $\chi^{2}=13.11 ; p<0.001$.

We analyzed gastrointestinal tract disorders in the examined women and revealed that 4 women $(12.5 \pm 11.92 \%$, $\left.\chi^{2}=2.40 ; p=0.121\right)$ in the first group $(n=33)$ suffered from chronic gastritis, and 3 $\left(9.09 \pm 10.19 \%, \quad \chi^{2}=1.40 ; \quad p=0.237\right) \quad$ had chronic pancreatitis; functional bowels disorders (notably, irritable bowels syndrome) were detected in 1 patient $(3.03 \pm 6.08 \%)$, gall bladder disorders (including gall bladder dyskinesia and biliary tracts dyskinesia) were also detected in only 1 patient $(3.03 \pm 6.08 \%)$. We didn't detect any urinary system disorders (chronic pyelonephritis, cystitis, or urethritis), or thyroid gland disorders (hypothyroidism or hyperthyroidism) in women from the first group. We detected 2 cases $\left(6.06 \pm 8.46 \%, \chi^{2}=0.52\right.$; 
$\mathrm{p}=0.473$ ) of chronic respiratory tracts disorders (chronic pharyngitis, rhinitis, or rhinopharyngitis). More than half of them had food allergy or household chemicals allergy, $6\left(18.18 \pm 13.68 \%, \chi^{2}=4.52 ; p=0.003\right)$ women had broad spectrum antibiotics allergy.

Gastrointestinal tract diseases analysis in the 2nd group $(n=42)$ revealed that $57.14 \pm 15.42 \%$ had chronic gastritis, and $42.86 \pm 15.42 \%$ were healthy, $\chi^{2}=30.86$; $\mathrm{p}<0.001$; chronic pancreatitis was detected in $23.81 \pm 13.27 \%$ (10 women), $\chi^{2}=9,19$; $\mathrm{p}=0.002$; bowels functional disorders, in $64.29 \pm 14.93 \% \quad$ (27 patients), $\quad \chi^{2}=36.90$; $\mathrm{p}<0.001$; gall bladder disorders were detected in $61.9 \pm 15.13 \%$ (26) cases, $\chi^{2}=34.81 ; \quad \mathrm{p}<0.001 . \quad 21 \quad$ patients $(50 \pm 15.58 \%)$, had urinary system diseases $\chi^{2}=25.40 ; p<0.001$. Thyroid gland diseases were detected in $5(11.9 \pm 10.09 \%)$ women; chronic respiratory tract diseases, in particular, chronic rhinitis, in $19.05 \pm 12.24 \%$ patients, $\chi^{2}=6.77 ; p=0.009$, and chronic rhinopharyngitis, in $28.57 \pm 14.08 \%, \chi^{2}=11.76$, $\mathrm{p}<0.001 .15$ patients $\left(35.71 \pm 14.93 \%, \chi^{2}=\right.$ $15.91 ; \mathrm{p}<0.001)$ had broad spectrum antibiotics allergy.
We applied Mann-Whitney criterion and revealed statistically significant discrepancies between 2 groups as per blood analysis. Notably, women from the groups 2 (patients with chronic endometritis) had greater quantities of stab neutrophils, lymphocytes, and monocytes, as well as low erythrocytes sedimentation rates, which could possibly indicate their immune protection was weaker, and their non-specific body reactivity, lower (Table 2).

Comparison between patients from the 1 st and 2nd group allowed to reveal statistically significant discrepancies between occurrence frequency of such diseases as chronic gastritis, bowels functional disorders, gall bladder diseases, urinary system diseases, and chronic rhinopharyngitis. the above-mentioned pathologies occurred more frequently in patients suffering from chronic endometritis. We also detected statistically insignificant discrepancies between occurrence frequency of such parameters as body mass index deviations, chronic pancreatitis, chronic rhinitis, antibiotics allergy in groups of healthy and sick women. Comparative characteristics of the above-mentioned pathologies is given in Table 3.

Table 2

Comparative characteristics as per blood analysis between 2 groups

\begin{tabular}{|l|c|c|c|}
\hline \multicolumn{1}{|c|}{ Blood analysis parameters } & $\begin{array}{c}\text { group1 } \\
(\mathrm{n}=33) \\
\mathrm{Me} \\
(25 \%-75 \%)\end{array}$ & $\begin{array}{c}\text { group 2 } \\
(\mathrm{n}=42) \\
\mathrm{Me} \\
(25 \%-75 \%)\end{array}$ & p-level \\
\hline Leucocytes $\left(10^{*} 9\right)$ & $5,2(4,7-5,5)$ & $4,7(4,1-5,3)$ & $0,029^{*}$ \\
\hline Stab neutrophils (\%) & $2(1-2)$ & $2(2-3)$ & $0,005^{*}$ \\
\hline Monocytes (\%) & $9(6-10)$ & $11(9-12)$ & $0,003^{*}$ \\
\hline Lymphocytes (\%) & $31(27-35)$ & $36(33-40)$ & $0,001^{*}$ \\
\hline Thrombocytes $\left(10^{*}\right)$ & $244(226-286)$ & $221(211-267)$ & $0,024^{*}$ \\
\hline Erythrocytes sedimentation rate $(\mathrm{mm} / \mathrm{h})$ & $13(11-15)$ & $7(5-12)$ & $0,001^{*}$ \\
\hline Hemoglobin $\mathrm{g} / 1$ & $127(124-132)$ & $124(114-134)$ & 0,246 \\
\hline
\end{tabular}

Note:* - means Mann-Whitney criterion allowed to reveal statistically significant discrepancies between 2 groups. 
Table 3

Comparative characteristics of somatic pathologies between groups

\begin{tabular}{|l|c|c|c|c|c|c|}
\hline \multicolumn{1}{|c|}{ Parameter } & $\begin{array}{c}\text { Group } \\
1(\mathrm{n}=33) \\
\%\end{array}$ & $\begin{array}{c}\text { Group 2 } \\
(\mathrm{n}=42) \\
\%\end{array}$ & $\mathrm{Chi}^{2}$ & $\mathrm{P}$ & OR & CI 95\% \\
\hline BMI & $30,3 \pm 16,3$ & $30,95 \pm 14,4$ & 0,04 & 0,848 & 1,031 & 0,$38 ; 2,77$ \\
\hline Chronic gastritis & $12,5 \pm 11,9$ & $57,14 \pm 15,4$ & 13,6 & $0,001^{*}$ & 9,333 & 2,$78 ; 31,39$ \\
\hline Chronic pancreatitis & $9,09 \pm 1,01$ & $23,81 \pm 13,2$ & 1,9 & 0,172 & 3,125 & 0,$78 ; 12,46$ \\
\hline Bowels functional disorders & $3,03 \pm 6,0$ & $64,29 \pm 14,9$ & 27,1 & $0,001^{*}$ & 57,60 & 7,$14 ; 464,79$ \\
\hline Gall bladder diseases & $3,03 \pm 6,0$ & $61,9 \pm 15,1$ & 25,3 & $0,001^{*}$ & 52,00 & 6,$46 ; 418,55$ \\
\hline Urinary system diseases & 0 & $50,0 \pm 15,5$ & 12,2 & $0,001^{*}$ & - & - \\
\hline Thyroid gland diseases & 0 & $11,9 \pm 10,0$ & 1,1 & 0,300 & - & - \\
\hline Chronic rhinitis & $6,06 \pm 8,4$ & $19,05 \pm 12,2$ & 1,4 & 0,229 & 3,412 & 0,$67 ; 17,36$ \\
\hline Chronic rhinopharyngitis & $6,06 \pm 8,4$ & $28,27 \pm 14,0$ & 4,8 & $0,029 *$ & 6,200 & 1,$28 ; 30,07$ \\
\hline Antibiotics allergy & $18,18 \pm 13,0$ & $35,71 \pm 14,9$ & 2,015 & 0,156 & 2,500 & 0,$84 ; 7,41$ \\
\hline
\end{tabular}

Note: * - means that statistically significant discrepancies in a parameter occurrence frequency were detected between healthy women and those suffering from chronic endometritis.

When we calculated relative health disorders risk in terms of a significant somatic pathology in patients suffering from chronic endometritis, we obtained the following results: chronic gastritis risk (RR) was equal to 2.190 , OR $95 \% 1.48 ; 3.24$; bowels functional disorders (RR), 3.021, OR 95\% 1.98;4.62; gall bladder diseases (RR), 2.889, OR 95\% 1.92;4.34; urinary system diseases (RR), 2.571, OR 95\% 1.84;3.59; chronic rhinopharyngitis (RR) 1.743, OR 95\% 1.25;2.43 (correlation was thought to be significant at $\mathrm{p}<0.05)$, and it indicated that women from the 2nd group ran higher risks of somatic pathologies oc- currence. Bearing our research goals in mind, we analyzed women's questionnaires as per life quality and revealed statistically significant discrepancies between two groups as per two scales. We should highlight that patients suffering from chronic endometritis had lower Role-Emotional functioning capacities, greater anxiety, mental ill-being, lower health self-esteem and lower resistance to diseases, they assessed their treatment prospects skeptically, and all this undoubtedly meant life quality of these women was rather poor (comparison results are given in Table 4).

Table 4

Comparative characteristics of life quality between 2 groups

\begin{tabular}{|l|c|c|c|}
\hline \multicolumn{1}{|c|}{ Parameters } & $\begin{array}{c}\text { Group 1 (n=33) Me } \\
(25 \%-75 \%)\end{array}$ & $\begin{array}{c}\text { Group 2 (n=42) Me } \\
(25 \%-75 \%)\end{array}$ & p-level \\
\hline Physical functioning & $65(59-68)$ & $44(42-54)$ & $<0,001^{*}$ \\
\hline Role physical functioning & $68(67-71)$ & $47(44-49)$ & $<0,001^{*}$ \\
\hline Bodily pain & $71(69-74)$ & $43,5(38-47)$ & $<0,001^{*}$ \\
\hline Vitality & $71(70-73)$ & $48(45-51)$ & $<0,001^{*}$ \\
\hline Social functioning & $72(70-75)$ & $55(48-56)$ & $<0,001^{*}$ \\
\hline Role emotional state & $77(74-79)$ & $40,5(37-45)$ & $<0,001^{*}$ \\
\hline Mental health & $80(72-82)$ & $42(38-45)$ & $<0,001^{*}$ \\
\hline General health & $69(60-72)$ & $44,5(43-55)$ & $<0,001^{*}$ \\
\hline
\end{tabular}

Note: $\mathrm{p}<0.001 *$ - means Mann-Whitney criterion allowed to reveal statistically significant discrepancies between 2 groups. 
Conclusions. Health parameters of patients suffering from chronic endometritis differ greatly from those of healthy women. High somatic pathology parameters and fertility issues can cause low scores of each life quality scale. Analysis of life quality which patients with this diseases have will allow to develop relevant recommendations aimed at its improvement and exerting positive influence on efficiency of the basic pathology therapy. Allowing for poor health of women suffering from chronic endometritis, we assume that doctors with all specialties should pay greater attention to medical-preventive activities, and prescribe health-preserving treatment at all the stages when a woman applies for medical aid, and not only when she is getting ready for a pregnancy. It is necessary to apply individualized sets of pharmaceuticals, physiotherapeutic and balneal techniques, as well as diet therapy, for the recovery of basic metabolism types, antioxidant processes, immunologic protection factors and non-specific reactivity. Healthpreserving treatment for not only gynecological but also concomitant somatic pathologies can stimulate adaptation reserves recovery in organs and systems, neuro-vegetative regulation, and, accordingly, hormonal homeostasis recovery which becomes truly vital for maintaining proper reproductive system functioning.

\section{References}

1. Demin A.V. Populyatsionnye pokazateli kachestva zhizni zhenshchin 65-74 let, prozhivayushchikh na Evropeiskom Severe Rossii [Population parameters of life quality characteristic for women aged 65-74 living in the Northern European part of Russia]. Molodoi uchenyi, 2015, no. 21, pp. 261-269. Available at: https://moluch.ru/archive/101/22786/ (09.07.2017) (in Russian).

2. Dolgikh O.V., Zaitseva N.V., Dianova D.G. Analiz apoptoticheskoi aktivnosti limfotsitov u zhenshchin fertil'nogo vozrasta $\mathrm{v}$ usloviyakh vozdeistviya reprotoksikantov [In women of childbearing age under the conditions of reprotoxicants exposure]. Rossiiskii immunologicheskii zhurnal, 2015, vol. 9, no. 1, pp. 58 (in Russian).

3. Loranskaya I.D., Rakitskaya L.G., Malakhova E.V., Mamedova L.D. Lechenie khronicheskikh kholetsistitov [Chronic cholecystitis treatment]. Lechashchii vrach: meditsinskii nauchno-prakticheskii portal, 2006. Available at: https://www.lvrach.ru/2006/06/4534015/ (10.08.2017) (in Russian).

4. Minasyan A. M., Dubrovskaya M. V. Beremennost' na fone khronicheskogo pielonefrita (obzor) [Pregnancy of a woman suffering from chronic pyelonephritis (a review)]. Saratovskii nauchno-meditsinskii zhurnal, 2012, vol. 8, no. 4, pp. 920-925 (in Russian).

5. Orazmuradov A.A., Boltovskaya M.N., Shmel'kov A.V., Apresyan S.V., Nazimova S.V., Terent'eva S.L. Negativnoe vliyanie khronicheskogo pielonefrita na protsess gestatsii [Negative impact of chronic pyelonephritis on the gestation]. Vestnik Rossiiskogo universiteta druzhby narodov. Seriya: Meditsina, 2011, no. S5, pp. 14-18 (in Russian).

6. Ovchinnikov A.Yu., Slavskii A.N., Fetisov I.S. Khronicheskii tonzillit i sopryazhennye s nim zabolevaniya [Chronic tonsillitis and concomitant diseases]. Russkii meditsinskii zhurnal, 1999, no. 7, pp. 31-36 (in Russian).

7. Bubnova O.A., Dolgikh O.V., Sinitsyna O.O., Krivtsov A.V., Bezruchenko N.V., Mazunina A.A., Gusel'nikov M.A., Otavina E.A. Polimorfizm genov semeistva ppars, gena esr1 u zhenshchin $\mathrm{s}$ nevynashivaniem beremennosti $\mathrm{v}$ usloviyakh aerogennoi ekspozitsii fenolami [Polymorphism of ppars genes and esr1 gene in females with miscarriages under aerogenous exposure to phenols]. Okruzhayushchaya sreda i zdorov'e. Gigiena i ekologiya urbaniziro- 
vannykh territorii: materialy VI Vserossiiskoi nauchno-prakticheskoi konferentsii s mezhdunarodnym uchastiem molodykh uchenykh i spetsialistov, posvyashchennoi 85-letiyu FGBU NII ECh i GOS im. A.N. Sysina Minzdrava Rossii [Environment and health. Hygiene and ecology on urbanized territories: materials of the VI Russian theory and practical conference with international participation of young scientists and experts dedicated to 85-th anniversary of Sytin's Scientific Research Institute for Human Ecology and Environmental Hygiene of the RF Public Healthcare Ministry]. In: Yu.A. Rakhmanin, ed. 2016, pp. 93-98 (in Russian).

8. Amirdzhanova V.N., Goryachev D.V., Korshunov N.I., Rebrov A.P., Sorotskaya V.N. Populyatsionnye pokazateli kachestva zhizni po oprosniku SF-36 (rezul'taty mnogotsentrovogo issledovaniya kachestva zhizni «MIRAZh») [SF-36 questionnaire population quality of life indices Objective]. Nauchno-prakticheskaya revmatologiya, 2008, no. 1, pp. 36-48 (in Russian).

9. Radzinskii V.E. Reproduktivnaya infektologiya XXI veka [Reproductive infectology in the XXI century]. StatusPraesens, 2013, no.16-5, pp. 33-36 (in Russian).

10. Fen I., Sidorova I.S., Stanoevich I.V., Unanyan A.L., Kudrina E.A. Sochetanie giperplasticheskikh protsessov endometriya s khronicheskim endometritom [Combination of endometrial hyperplastic processes with chronic endometritis]. Akusherstvo, ginekologiya i reproduktsiya, 2012, vol. 6, no. 1, pp. 31-33 (in Russian).

11. Motovilova T.M., Grechkanev G.O., Kachalina T.S., [et al.]. Sravnitel'naya kharakteristika mikroflory polosti matki i nebnykh mindalin u patsientok s persistiruyushchim endometritom [Comparative characteristics of microflora of uterine cavity and palatal tonsils in the case of female patients having persistent endometritis]. Meditsinskii al'manakh, 2015, no. 4 (39), pp. 105-107 (in Russian).

12. Sukhikh G.T., Shurshalina A.V. Khronicheskii endometrit [Chronic endometritis]. Moscow, GEOTAR-Mediya, Publ., 2010, 64 p. (in Russian).

13. Styazhkina S.N., Chernenkova M.L., Krivenko P.A., Gailyamova L.I. Techenie i iskhody beremennosti $\mathrm{u}$ zhenshchin $\mathrm{s}$ khronicheskim pielonefritom [The course of pregnancy and outcome of labor in women with chronic pyelonephritis]. Sovremennye problem nauki i obrazovaniya: elektronnyi nauchnyi zhurnal, 2015, no. 1-1. Available at: https://www.scienceeducation.ru/ru/article/view?id=17394 (12.07.2017) (in Russian).

14. Tkachenko L.V., Sviridova N.I. Prognosticheskie faktory riska razvitiya giperplasticheskikh protsessov endometriya v perimenopauzal'nom periode [Prognostic factors for the development of hyperplastic processes in perimenopause]. Volgogradskii nauchno-meditsinskii zhurnal, 2013, no. 4, pp. 43-47 (in Russian).

15. Chereshnev V.A., Gusev E.Yu. Immunologiya vospaleniya: rol' tsitokinov [Immunology of Inflammation: The Role of Cytokines]. Meditsinskaya immunologiya, 2001, vol. 3, no. 3, pp. 361-368 (in Russian).

16. Ware J.E., Snow K.K., Kosinski M., Gandek B. SF-36 Health Survey. Manual and interpretation guide. Boston, Mass: The Health Institute, New England Medical Center, 1993.

17. Ware J.E., Kosinski M., Keller S.D. SF-36 Physical and Mental Health Summary Scales: A User`s Manual. Boston, Mass: The Health Institute, New England Medical Center, 1994.

Kobaidze E.G., Padrul M.M. High risks of somatic pathology in women with chronic endometritis. Health Risk Analysis, 2017, no. 4, pp. 57-65. DOI: 10.21668/health.risk/2017.4.06.eng

Received: 08.09.2017

Accepted: 11.12.2017

Published: 30.12 .2017 